\title{
A ROMAN SARCOPHAGUS FROM TATABÁNYA
}

\author{
PÉTER KOVÁCS*-SÁNDOR PETÉNYI** \\ *Pázmány Péter Catholic University, Egyetem u. 1, H-2081 Piliscsaba, Hungary \\ Universität Wien, Institut für Alte Geschichte und Altertumskunde, Papyrologie und Epigraphik \\ kovacs.peter@btk.ppke.hu \\ ** KunyDomokos Museum, Váralja u. 3, H-2890 Tata, Hungary \\ petenyi.sandor@kunymuzeum.hu
}

\begin{abstract}
In this paper the authors publish a new sarcophagus from Tatabánya found in 1989. The funerary inscription was erected to a tesserarius who served in the legio I adiutrix in Brigetio and other living members of the family by his half-brother. Based on the names the stemma of the family can be restored. The tesserarius was depicted on the frontal side with the hastile of the optiones in his hand. Based on the text, the palaeography and the rich decorated sarcophagus, it can be dated to the $2^{\text {nd }}$ half of the $3^{\text {rd }}$ century and it was made in a local workshop in Brigetio.
\end{abstract}

Keywords: Roman Pannonia, Epigraphy, Sarcophagus, Brigetio, Military history

In the territory of Tatabánya (County Komárom-Esztergom) several Roman Age stone monuments were found, all of them are tombstones (RIU 716-721), earlier a Roman sarcophagus came to light in Alsógalla (today part of the town) (RIU 696). In this paper we shall publish another sarcophagus. ${ }^{1}$ Several members of the families known from the funerary inscriptions of Tatabánya served in the legio I adiutrix in Brigetio (RIU 718-720). The same can be observed in the case of the new sarcophagus too.

\section{THE PROVENANCE}

In July 1989 in the plot No. 56 Május 1 Street in Tatabánya during digging a water-conduit a Roman stone monument was found and reported to the museum (Fig. 1). During the rescue-excavation executed by Sándor Petényi the whole sarcophagus was unearthed and transported into the Museum of Tatabánya. The sarcophagus was robbed and it was found in secondary place (Figs 2-4). The lid of the sarcophagus is lost but several fragments were found in the area of the digging. One of them can be identified with the middle acroterium of the lid (InvNr. 91.15.1) (Fig. 5). Human bones were found neither in the sarcophagus nor nearby. Only fragments of a yellowish brown lead-glazed small beaker with pine cone-like scaled decoration came to light (base/body and ribbed rim fragments: InvNr. 91.1.1 and 5) (Figs 6-7). The most similar vessel was found in the late Roman so-called "augur"-cemetery of Brigetio 400-500 m SW of the legionary fort (in grave No. 7). ${ }^{2}$ Based on the grave-furniture the grave was dated

${ }^{1}$ The paper is dedicated to the memory of Barnabás Lörincz who dealt with the inscription first. We wish thank Dr Katalin
Ottományi for her help. The map was prepared by József Kaszál, the photoes were taken by István Dallos.

${ }^{2}$ BARKÓCZI 1968, 75-81. 

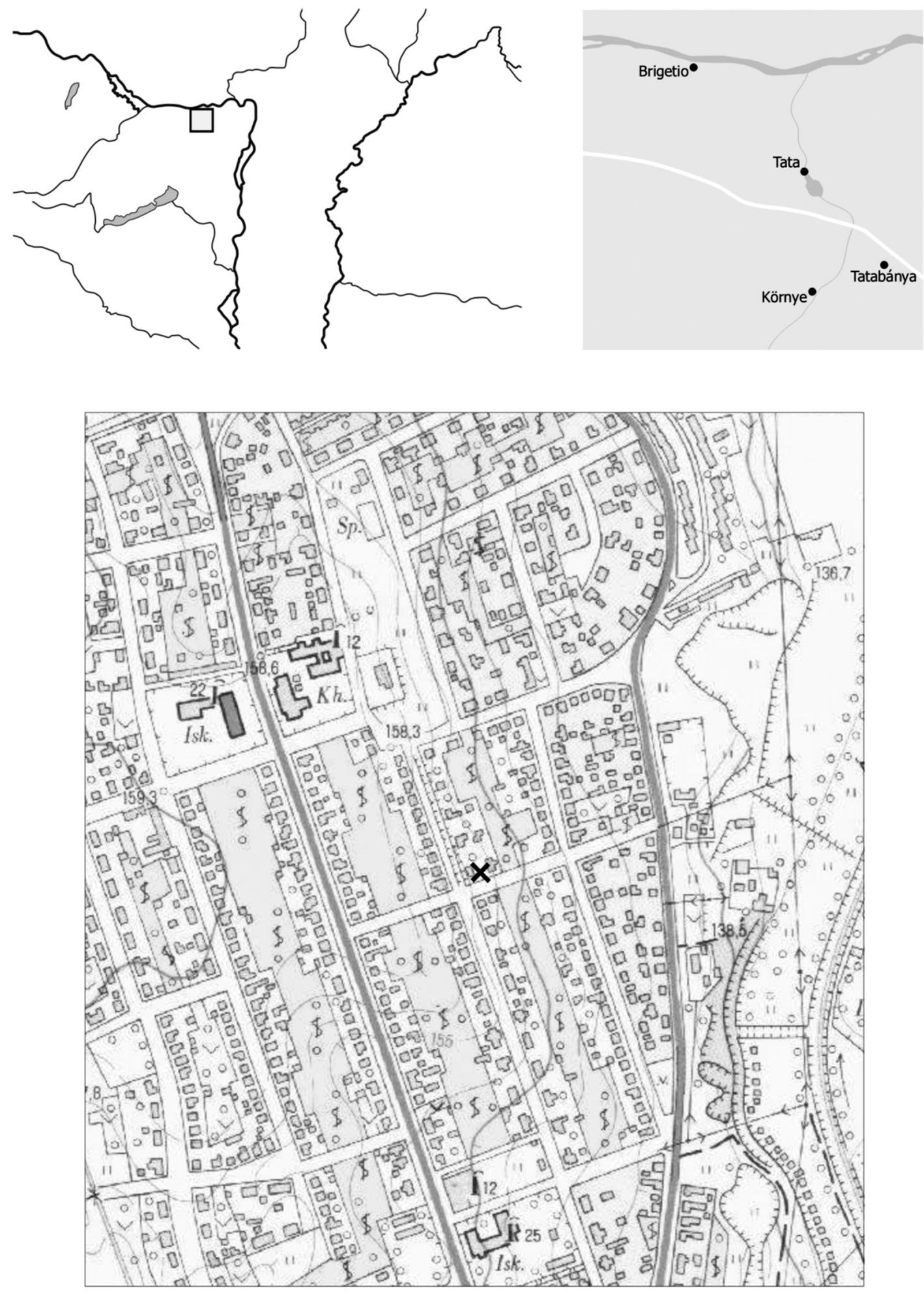

Tatabánya-Kertváros

Fig. 1. The find-spot of the sarcophagus 


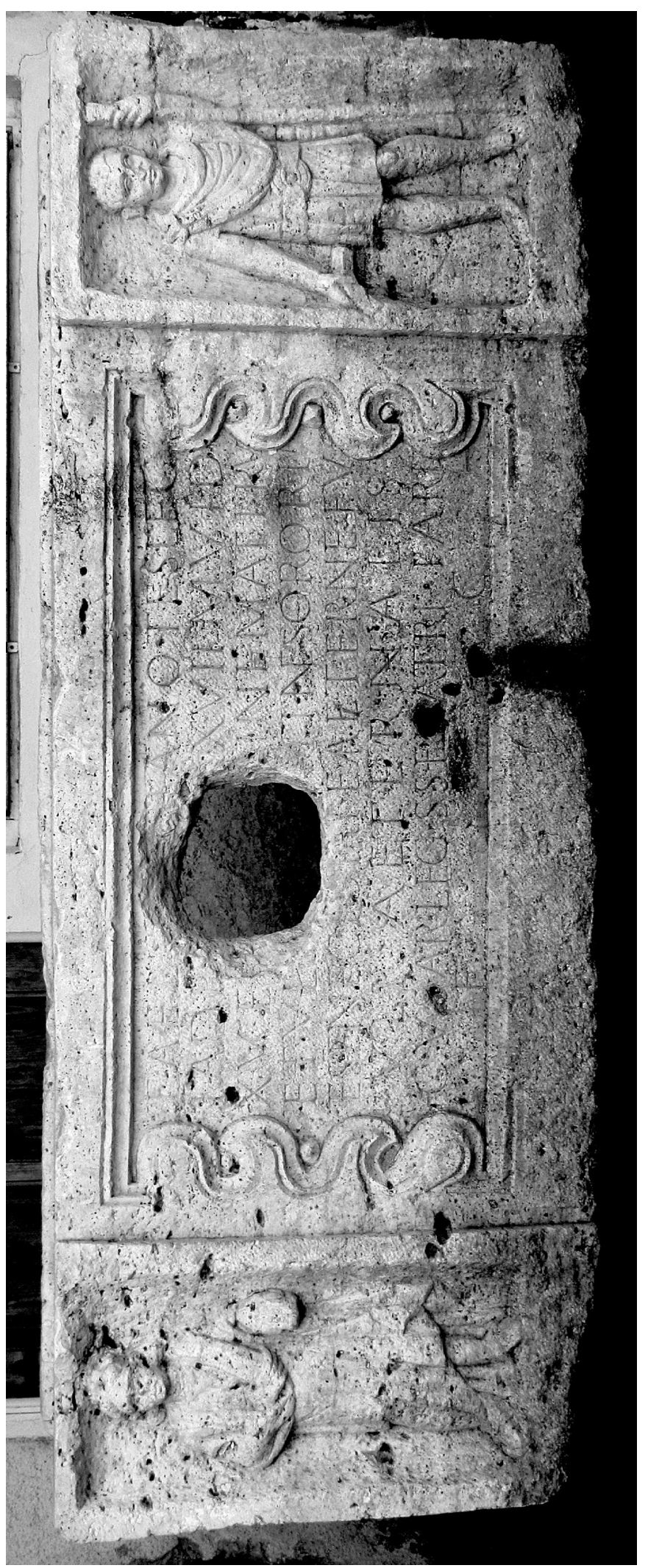




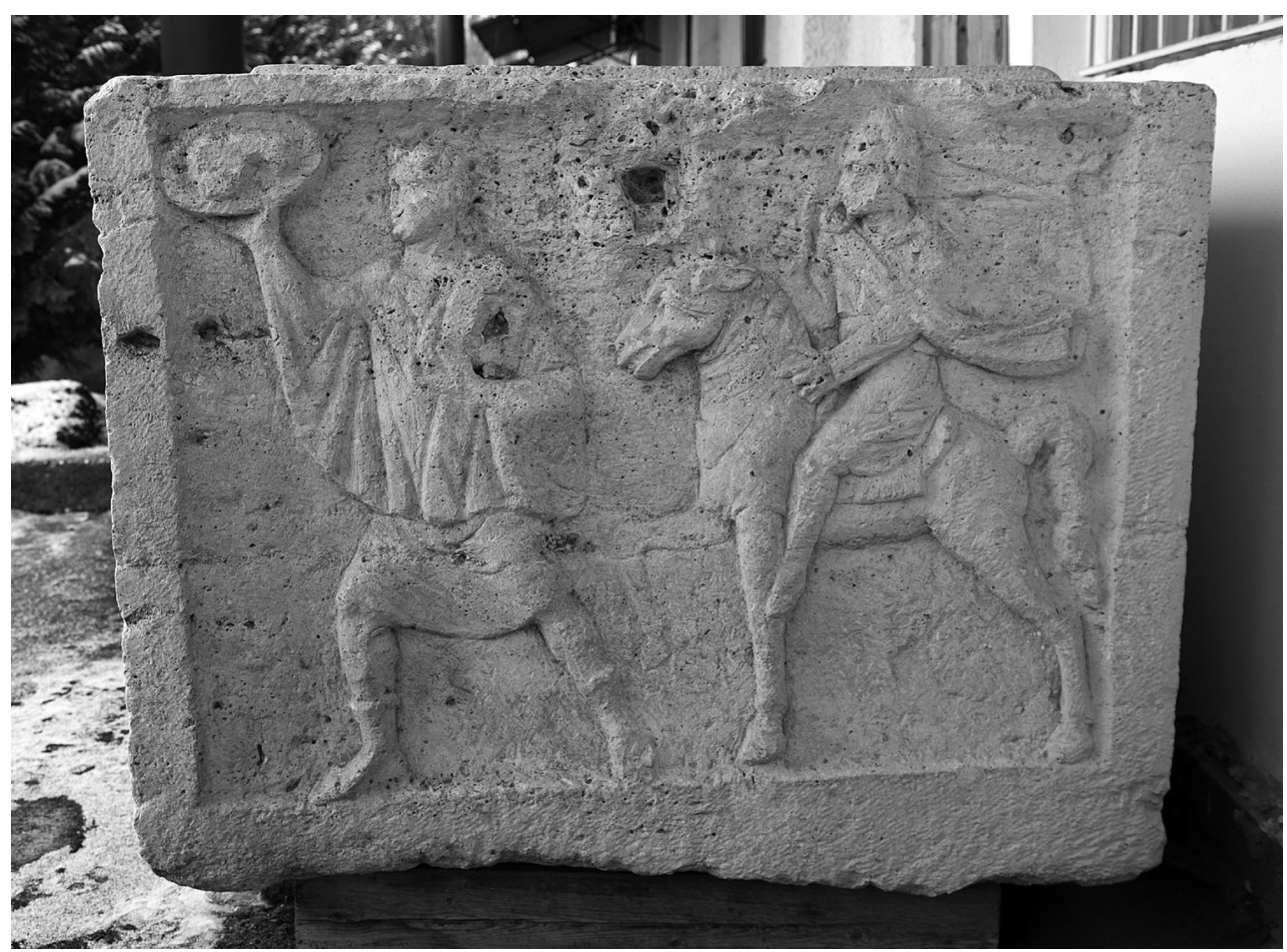

Fig. 3. The sarcophagus, right narrow side

to the end of the $3^{\text {rd }}$ - beginning of the $4^{\text {th }}$ century ${ }^{3}$ and L. Barkóczi mentioned another unpublished vessel, also from Brigetio, that must similarly be dated based on a Licinius coin found in the same grave. ${ }^{4}$

\section{THE SARCOPHAGUS AND THE INSCRIPTION}

Limestone sarcophagus, without its lid (InvNr. 91.14.1; Figs 2-4).

Height: 77, width: 210, depth: $103 \mathrm{~cm}$. The height of the letters: 3,8 (line 1), 4,2 (line 2), 4 (line 3), 4,3 (line 4), 4 (line 5-6), 4,3 (line 7) cm. Now it can be found in Tatabánya, depot. In the middle upper part of the epigraphic field a large hole is visible (diam.: $27 \mathrm{~cm}$ ). Several other smaller holes (secondary: $\mathrm{cp}$. the damaged letter $\mathrm{R}$ in line 7) can be observed on its surface. Besides the epigraphic field in niche standing male and female figures can be found. To the left a female figure wears long stola and pallium and she holds a casket in her left hand. To the right a bearded man wears a short tunica with cingulum militare and a sagum with a brooch. They can be identified with the dead tesserarius of the inscription and his mother. He has a long spatha and holds a scrolled cloth in his left hand. In his right a long wooden staff (widening at the top) can be observed. The left narrow side of the sarcophagus is divided by a pillar. To the left a hanging drape can be found, and to the right a camilla holding a patera and a jug stands. She wears a half-long belted tunica. On the right side of the sarcophagus the riding bearded tesserarius of the inscription can be seen who also wears tunica and floating sagum with a disc brooch. In his lifted right hand he holds the same scrolled cloth as in the main scene. In front of him a camillus runs. He wears a long, sleeved tunica (on his left shoulder with a mantele/panna) and holds a dish with the meal of the funerary banquet in his lifted right hand. At the top of both narrow sides clamp holes are visible.

One fragment of the lost lid can be identified: it was part of the semi-circular middle acroterium with a young male portrait (InvNr. 91.15.1; $12 \times 14 \times 7 \mathrm{~cm}$ : Fig. 5), originally was most probably a half-figure representation. These acroteria in the area of Brigetio are always represented the dead family members but single figures are

${ }^{3}$ BARKÓCZI 1992, 30.

${ }^{4}$ BARKóCZI 1968, 81. 


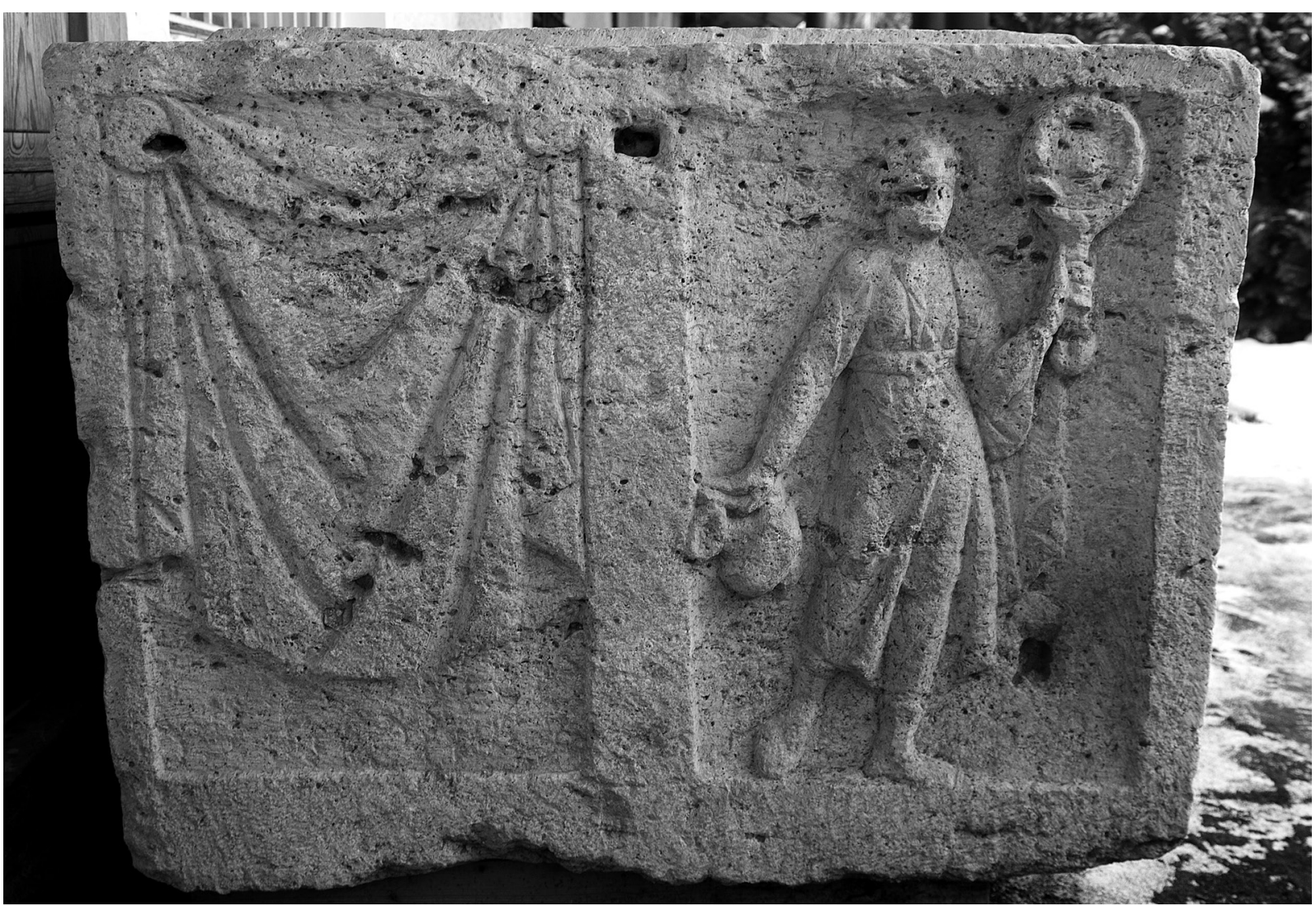

Fig. 4. The sarcophagus, left narrow side

known, too (e. g. RIU 524, 557). ${ }^{5}$ In this case the acroterium showed most probably only the tesserarius, i.e. the only dead person (see below).

The epigraphic field $(53 \times 113 \mathrm{~cm})$ is framed by Panno-Norican 'baroque' volutes and above and below a cymatium. The letters are regularly and attendingly carved, remnants of the red painting can be observed in several letters (especially in line 2). The clearly visible interpunctions are triangle-shaped, the lines are ordinated. The last letters (V) of line 3 and 4 (abbreviations of the adjective $v($ ivus )) are inscribed later. There are very few ligaturae in the text (only in the case of the conjunction et): Only one mistake of the stone-cutter can be observed: he mixed up the letter R and I in the word matri at the end of line 4. Vulgar Latin phenomena can also hardly be found in the text: the general letter $\mathrm{E}$ instead of the diphtong $\mathrm{AE}$, use of the letter $\mathrm{K}$ in the adjective carissimus. The first line of the inscription with the formula Dis Manibus (or a longer one) is most probably missing because it could have carved into the narrow frame of the lid.

The inscription can be restored as follows:

[D(is) M(anibus)?]

T(ito) Ael(io) [- - - jiano tes(serario) leg(ionis)

I ad(iutricis) p(iae) [f(idelis) vix(it) an(nos)] XXXVII m(enses) VI d(ies)

XV ê[t - - Jin(a)e matri v(ivae)

êt Ulp(iae) [Vale]ntin̂(a)e sorori v(ivae)

$5 \quad$ êt Senecioni êt Aetern(a)e f(iliis) v(ivis)

Ulp(ius) Aeternalis

cu(stas) ar(morum) leg(ionis) supras(criptae) fratri kari(ssimo)

$f($ aciendum) $c$ (uravit)

${ }^{5}$ PochMARSKI 2001, 202, 203, 204. 
The above-mentioned persons were earlier unknown. Ulpius Senecio, the aedilis of Carnuntum cannot be identified with Senecio as he erected with his colleague an altar Bonae Valetudini in the year 178 A.D. (AÉp 1905, 236). Another Ulpius Senecio from Carnuntum served as duplarius in the legio XIIII gemina in the $3^{\text {rd }}$ century (CIL III 11180). The funerary text was erected by the brother of the deceased tesserarius who had no family yet (he could be hardly elder than 27 years, there is no more room in the missing part of line 3). In text their mother, the sister of Aeternalis and his children are mentioned, all of them were still alive. Based on the different gentile names the brothers had common mother but different fathers. Because of chronological point of view (the sarcophagus cannot be dated earlier than the $3^{\text {rd }}$ century) it has to be excluded that the peregrine brothers would have received the Roman citizenship personally from Trajan and Antoninus Pius. Based on this fact, the mother had to have two marriages: earlier she married an Ulpius (they had a daughter and a son) and later she married an Aelius (born only one son, the tesserarius). The tesserarius was born later as he died relatively young and his half-brother had already family. As the fathers are not named in the funerary text they had to die earlier. Senecio and Aeterna are most probably the children of Aeternalis because they enumerated separately at the end of the inscription. The cognomina Aeterna and Aeternalis also attest a strong relationship between them. Their gentile names are omitted because of the same reason. Their mother was not named either therefore she probably died earlier too.

Based on this, the family tree can be restored as follows:

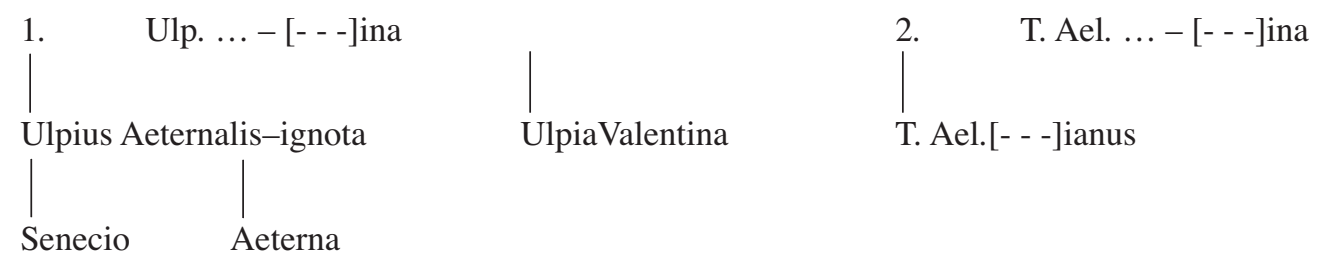

The ancestors of the family received the Roman citizenship under Trajan's and Antoninus Pius' rule, therefore their male descendants could serve in the legion of Brigetio. This fact can confirm the local origin of the family. Unfortunately, the cognomina of the tesserarius and his mother cannot be restored because of the too many possibilities: [- - - ianus $^{6}$ and [- - - ]ina. ${ }^{7}$ The also damaged cognomen of the sister was most probably Valentina as this is the most frequent name in Pannonia with the ending NTINA but other unlikely cognomina cannot be excluded either. ${ }^{8}$ The cognomina Aeterna, Aeternalis coming from the same root are hardly attested in Pannonia (only one single Aeternalis: RIU 221), ${ }^{9}$ from the Brigetio region only Aeternae are known: RIU 410, 696, the latter one from Tatabánya-Alsógalla. They cannot be identified based on the different gentile names: (Ulpia and Aurelia). The cognomina Senecio and Longina (very popular in soldier families) are frequently used in Pannonia, and they are also known in this region but they cannot refer to the origin of the family: RIU 338, 580, TRH 63, and RIU 594. ${ }^{10}$ Several other tesserarii and armorum custodes of the legio I adiutrix are epigraphically attested (tesserarii: RIU 599, 1351, TRH 97, armorum custodes: RIU 413, 582, 696). ${ }^{11}$

It is noteworthy to deal with the representations of the sarcophagus separately. It frequently occurs in the sarcophagi of Brigetio and its region that the dead persons are represented in the niches instead of genii (esp. in the case of soldiers: RIU 506, 529, 636). ${ }^{12}$ The best analogy of the sarcophagus was found in Brigetio (RIU 636). Its narrow sides are also decorated with a rider scene, one of them is divided by a similar pillar/column. Its epigraphic field has very similar volutes. What is absolutely unexpected that in the sarcophagus of Tatabánya the camillus and the camilla of the funerary banquet are shown. The camillus appears in the rider scene instead of the calo (as in the cited sarcophagus of Brigetio). Based on this parallel the sarcophagi are the products of the same workshop of

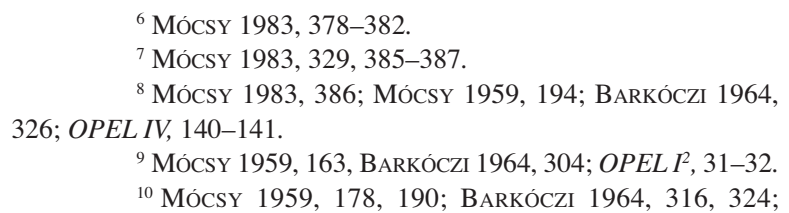

${ }^{8}$ Mócsy 1983, 386; Mócsy 1959, 194; BARKócZi 1964, 326; OPEL IV, 140-141.

${ }^{9}$ Mócsy 1959, 163, Barkóczi 1964, 304; OPEL $I^{2}, 31-32$.

${ }^{10}$ Mócsy 1959, 178, 190; BARKÓCZI 1964, 316, 324; OPEL III, 31, IV, 65. On the cognomen Longinus see A. MócsY:

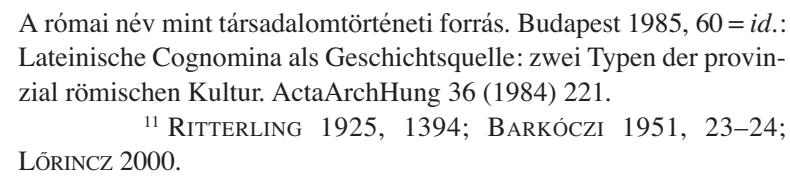

A római név mint társadalomtörténeti forrás. Budapest 1985, $60=i d$ : Lateinische Cognomina als Geschichtsquelle: zwei Typen der provinzial römischen Kultur. ActaArchHung 36 (1984) 221. LŐRINCZ 2000 


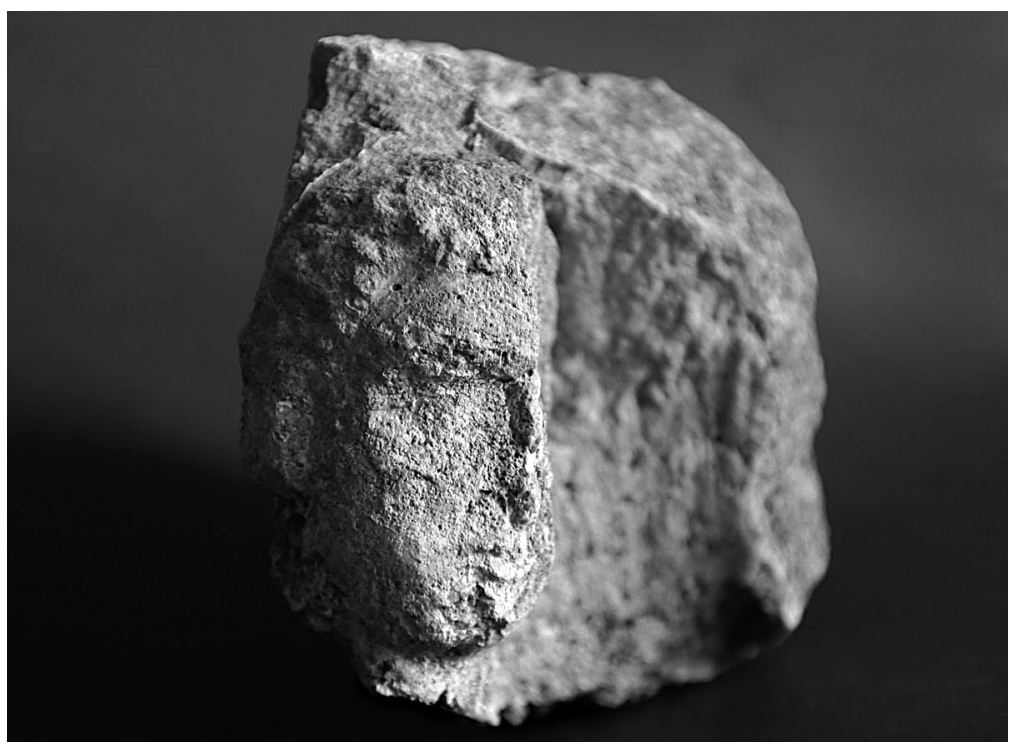

Fig. 5. Fragment of the middle acroterium

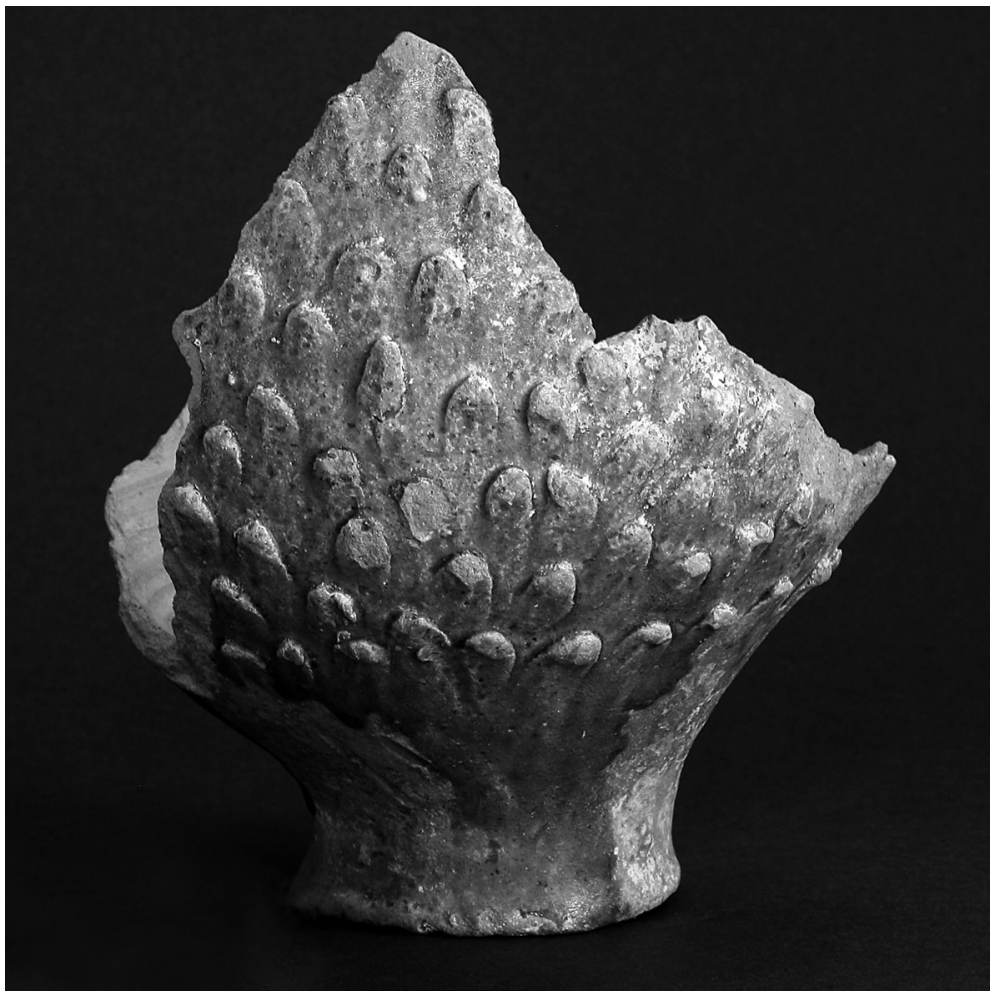

Fig. 6. Fragment of a lead-glazed beaker 


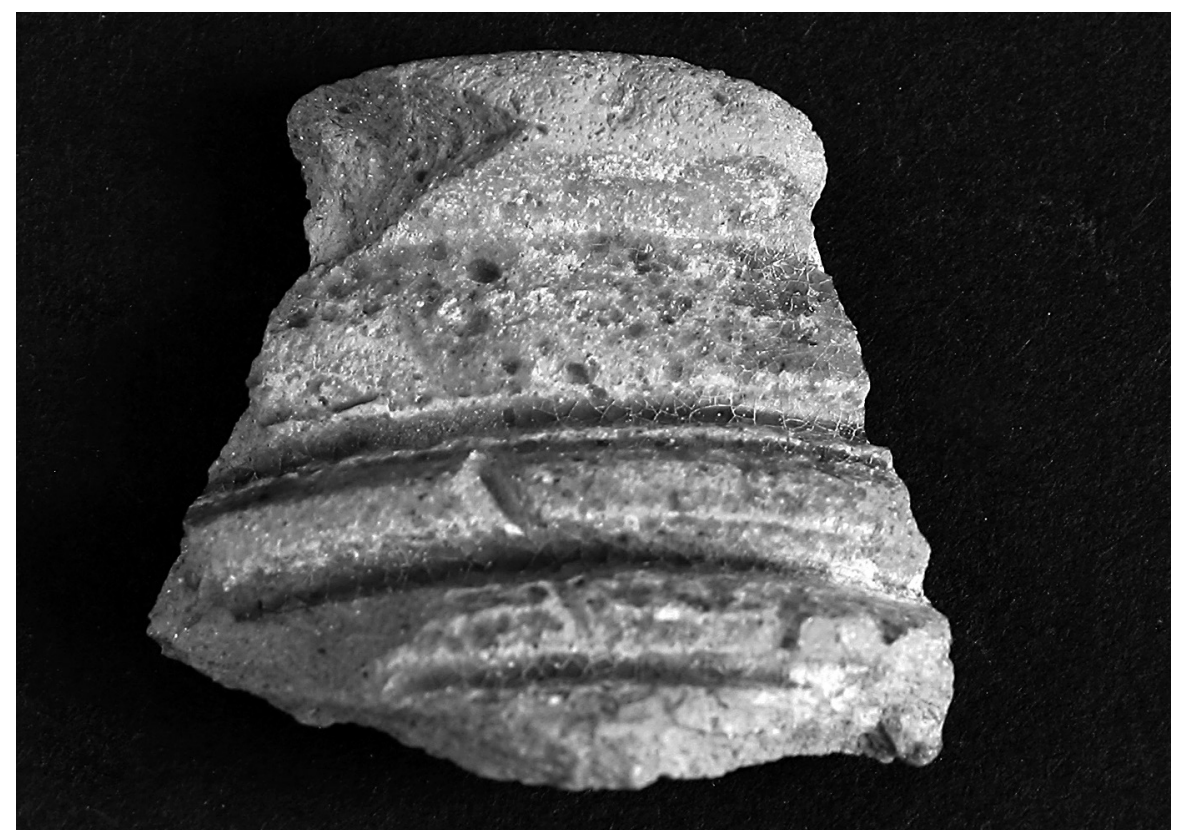

Fig. 7. Fragment of a lead-glazed beaker

Brigetio. The hanging drope (parapetasma) symbolizing the dividing line between the world and the netherworld can hardly be seen in Pannonian funerary stone monuments (cp. the Dacian tombstone CBFIR 536 from Samum - where the drope covers three figures with the exception of their heads). These dropes, otherwise, can frequently be seen in mythological sarcophagi in Italy and Rome. ${ }^{13}$ The Panno-Norican volutes exactly date the sarcophagus to the second half of the Severan Period, most probably to the reign Severus Alexander based on building inscriptions of Caracalla and the similar frames of sarcophagi of this period (cf. AÉp 2002, $1180=2005,1246$ ). ${ }^{14}$

To study the instruments in the hands of the tessararius is also noteworthy. The long staff cannot be identified with a spear, nor with the vitis of the centurions, nor with the fustis of the MP soldiers (as the beneficarii: cp. CIL VIII 9057 and the gem CIGP No. 39 from Carnuntum where the fustis is shown together with a beneficarius lance and ring-pommel sword ${ }^{15}$ ) as they are much shorter (but at the top of them a similar globe can be seen, cp. CIL VI 2602). ${ }^{16}$ Very similar staffs can be seen in the hands of the tesserarii of the legio II Parthica on the their tombstones in Apamea (one of them holds the tesserae, too) (AÉp 1993, 1585 and 1588). ${ }^{17}$ The tesserarii (named after tesserae with the watchwords) served in the Roman army among the principales as sesquiplicarii. They were responsible for getting watchwords from the commander and they assisted the optiones. ${ }^{18}$ Based on the rider scene the tesserarii could serve as rider soldiers, too (similarly to the optiones cp. ILJ 563 - Scupi). Based on this fact, the wooden staffs of the tesserarii can highly likely be identified with the hastile of the optiones. Their duty was to keep the troops in order with these hastilia at the rear of the centuria (Liv. XXXV.5.10 hastilibus caedentes terga 207, Nos 18-20.

${ }^{12}$ BarkócZi 1951, 40-42; Pochmarski 2001, esp. 206-

${ }^{13}$ C. ROBERT: Die antiken Sarkophag-Reliefs. II: Mythologische Cyklen. Berlin 1890, 168; W. LAMEERE: Un symbole pythagoricien dans l'art funéraire de Rome. BCH 63 (1939) 43-85.

${ }^{14}$ G. ALFÖLDY: Megjegyzések egy brigetioi szarkofágfelirathoz (CIL III 4327) - Bemerkungen zur Inschrift eines Sarkophages aus Brigetio. ArchÉrt 86 (1959) 70-72; Zs. MrÁv: Eine litterae aureae-Inschrift aus Intercisa. FolArch 49-50 (2001-2002) 207-233. Summarily see G. ERDÉLYI: A pannoniai síremlékek ornamentikája (Stílustörténeti tanulmány). Doktori értekezés. Eger 1929.
${ }^{15}$ H.-J. UBL: Gedanken zu einem Benefiziarierabzeichen aus Lauriacum. In: F. W. Leitner (Hrsg.): Carinthia Romana und die römische Welt: Festschrift für Gernot Piccottini zum 60. Geburtstag. Klagenfurt 2001, 382-384.

${ }^{16}$ M. P. SPEIDEL: The fustis as soldiers' weapon. AntAfr 29 (1993) 137-149.

${ }^{17} \mathrm{~J}$. C. BALTY-W. van ReNGEn: Apamea in Syria: The winter quarters of legio II Parthica. Roman gravestones from the military cemetery. Bruxelles 1993, 38, 44-45.

${ }^{18}$ M. Clauss: Untersuchungen zu den Principales des römischen Heeres von Augustus bis Diokletian: cornicularii, speculatores, frumentarii. Bochum 1973, 17-40. 
trepidantium et redire in ordines cogentes also cp. Maur. Strat. XII.8.17), but they were probably also used as direction indicator in battle. These hastilia are known in other Roman stone monuments, too (cp. Tit. Aq. 500, RIB 492). Originally, they were probably training wooden instruments ending in a metal globe instead of a spearhead. ${ }^{19}$ Similarly interesting is the scrolled cloth (mantele or mappa) in the right of the tesserarius. These clothes can be seen in the hand of a camillus/a in a funerary banquet scene, ${ }^{20}$ or on his shoulder (as in our sarcophagus). This cloth of the tesserarius must also be connected to the funerary banquets (or ritual purity: e. g. the bones could have been covered with similar clothes in the grave ${ }^{21}$ ). The mappa can also be found on other funerary stone monuments (mainly in Germania) in hands of the deads lying in cline (cf. e. g. RIU 718) (e. g. RIB 558, CIL XIII 8082, 8090, 8091, 8670, CSIR Deutschland III/1 Nr. 27, 31, 36, 38). A similar curving mappa can be observed in the hands of the Attis figures in another sarcophagus of Brigetio (RIU 737) (in several cases the mappae are very similar to the book scrolls therefore they can easily mixed up). ${ }^{22}$

Based on these, the grave monument was erected by Ulpius Aeternalis to his young tesserarius, his mother (still alive), his sister and his children. The names, the carefully carved letters, the 'baroque' volutes and the rich decoration all date the sarcophagus to the second half of the Severan Period (probably to the reign of Severus Alexander) that was made in local workshop of Brigetio.

\section{REFERENCES}

\begin{tabular}{|c|c|}
\hline BARKÓCZI 1951 & = L. BARKÓCZI: Brigetio. DissPann II.22. Budapest 1951. \\
\hline BARKÓCZI 1964 & $\begin{aligned}= & \text { L. BARKÓCZI: The population of Pannonia from Marcus Aurelius to Diocletian. ActaArchHung } 16 \\
& \text { (1964) 257-356. }\end{aligned}$ \\
\hline BARKÓCZI 1968 & $\begin{aligned}= & \text { L. BARKÓCZI: Négy késő római sír Brigetioból - Vier spätrömische Gräber aus Brigetio. KMMK } 1 \\
& (1968) 75-105 .\end{aligned}$ \\
\hline BARKÓCZI 1992 & $\begin{aligned}= & \text { L. BARKÓCZI: Frührömische glasierte Keramik in Ungarn. In: P. Kovács (Hrsg.): Glasierte Keramik } \\
& \text { in Pannonien. Székesfehérvár 1992, 7-35. }\end{aligned}$ \\
\hline LÖRINCZ 2000 & $\begin{array}{l}=\text { B. LôRINCZ: Legio I adiutrix. In: Y. Le Bohec-C. Wolff (Éd.): Les légions de Rome sous le Haut- } \\
\text { Empire. Collection du Centre d’Études Romaines et Gallo - Romaines. Nouvelle série 20. Lyon } \\
\text { 2000, 151-168. }\end{array}$ \\
\hline Mócsy 1959 & = A. Mócsy: Die Bevölkerung von Pannonien bis zu den Markomannenkriegen. Budapest 1959. \\
\hline Mócsy 1983 & $\begin{aligned}= & \text { A. Mócsy: Nomenclator provinciarum Europae Latinarum et Galliae Cisalpinae cum indice in verso. } \\
& \text { DissPann III.1. Budapest 1983, 341-342. }\end{aligned}$ \\
\hline OPEL & $\begin{array}{l}\text { B. LőRINCZ (Hrsg.): Onomasticon provinciarum Europae Latinarum. I. Editio nova aucta et emen- } \\
\text { data. Budapest 2005; B. LÖRINCZ (Hrsg.): Onomasticon provinciarum Europae Latinarum. II-IV. } \\
\text { Wien 1999-2002. }\end{array}$ \\
\hline POCHMARSKI 2001 & $\begin{aligned}= & \text { E. Pochmarski: Zur Ikonographie und Chronologie der römischen Sarkopahge aus Brigetio. } \\
& \text { BudRég } 34 \text { (2001) 203-221. }\end{aligned}$ \\
\hline RITTERLING 1925 & = E. RITTERLING: Legio. In: PWRE XII. Stuttgart 1924-1925, col. 1211-1829. \\
\hline UBL 1969 & $\begin{aligned}= & \text { H.-J. UBL: Waffen und Uniform des römischen Heeres der Prinzipatsepochen ach den Grabreliefs } \\
& \text { Noricums und Pannoniens. [Univ. Diss.] Wien } 1969 .\end{aligned}$ \\
\hline
\end{tabular}

${ }^{19}$ UBL1969, 434-437, M. P. SPEIDEL: The framework of an Imperial legion. In: R. J. Brewer (ed.): Birthday of the Eagle: The second Augustan legion and the Roman military machine. Cardiff 2002, 134-135.

${ }^{20}$ A. V. SiEBERT: Instrumenta sacra: Untersuchungen zu römischen Opfer-, Kult- und Priestergeräten. Berlin 1999, 108-110, 262-263; ThesCRA V (2005) 187-188.
${ }^{21}$ R. N. SOLER VILABELLA: Una stoffa romana bimillenana la , mappa” dell'Antiquarium del governatorato di Roma. Bull. della comm. arch. com. di Roma 65 (1937) 73-82.

${ }^{22}$ A. Burger: Áldozati jelenet Pannonia kőemlékein. RégFüz II.5. Budapest 1959, 10. 